\title{
Inventory and Ratio Analysis
}

\author{
CS Gowtham, S.Praveen Kumar, J.Hameed Hussain
}

\begin{abstract}
Inventories are rough materials, work-in-process items and completely finished product that are seen as the section of business' points of interest that are arranged or will be readied accessible to be obtained. Itemizing a sensible stock model is one of the genuine stresses for an industry. The most timely intelligent stock organization explores return to the second decade of the earlier century, anyway the eagerness for this legitimate area is up 'til now mind boggling. There is distinctive stock control technique, for instance, Economic solicitation sum, reorder point, security blend, etc. [1],[3],[5]

Stock is the most ludicrous assets of a collecting association. Stock decisions honestly impact the estimation of cost of product sold and in this way expect a fundamental employment in choosing the declared pay of an association. As needs be, a serious examination of stock valuation and related records can give a reason to looking over the budgetary position of a firm. [2 ],[4],[6] Fixed assets generally called generous assets or property, plant and equipment, is a term used in speaking to assets and property that can just with critical exertion be changed over into cash. This can be differentiated and current assets, for instance, cash or budgetary adjusts, which are depicted commercial liquid assets. Guideline speaking, simply significant assets are implied as fixed. Also, a fixed/non-current asset can moreover be described as a bit of leeway not really offered to an organization's clients/end-customers. Fixes assets are planned for use for quite a while. The estimation of these favorable circumstances decreases with their use or with time or various reasons.. [7],[ 9],[11]
\end{abstract}

Keywords : Assets,cost,analysis

\section{INTRODUCTION}

Inventories are unrefined materials, work-in-process items and completely finished product that are seen as the bit of business' points of interest that are arranged or will be readied accessible to be bought. Itemizing a proper stock model is one of the critical stresses for an industry. The most reliable sensible stock organization investigates return to the second decade of the earlier century, anyway the excitement for this consistent zone is so far mind boggling. Again, considering the constancy of any system is a critical segment in the assessment works out. Estimations of specific segments are hard to portray or for all intents and purposes shocking. In such cases, feathery models of stock organization expect a noteworthy position. This paper analyzes potential parameters of existing models of stock

Revised Manuscript Received on July 22, 2019.

CS.Gowtham, Department of MBA, Bharath Institute of Higher Education and Research, Tamilnadu, India.. Email: chakravins@gmail.com

Dr.S.Praveen Kumar, Department of MBA, Bharath Institute of Higher Education and Research, Tamilnadu, India.. Email: praveenkumar.mba@bharathuniv.ac.in

Dr.J.Hameed Hussain, Department of Mehanical Engineering, Bharath Institute of Higher Education and Research, Tamilnadu, India.. Email: deanengg@bharathuniv.ac.in control. An undertaking is made to give a cutting edge review of existing composition, concentrating on delineations of the characteristics and sorts of stock control models that have been made. [14],[16], [18]

The stock is interface between the age and the appointment technique. The activity of stock organization is to check the openness of material as and when required the measure of the stock and if it's possible to confine the enthusiasm for stock. In the present forceful universe of amassing associations are glancing through better methodologies for improving the business strategy, how to satisfy the customer and by following this how they can stay ahead with their adversaries in the domain of competition. The procedure that can breath life into these things for past decades. This addresses money will be tied up until the stock leaves the association as purchased things, on account of tremendous size of inventories kept up by firms a proportion of advantages are required. It is subsequently totally essential to regulate inventories beneficially and feasibly in order to ignore the trivial theories. A firm who is rejecting the administering of inventories will be in risk at its long run efficiency and may bomb finally. [8],[ 10] ,[12]

\section{OBJECTIVES OF THE STUDY}

\section{Primary Objective}

To investigate the general stock and fixed resources execution of Ford India Pvt Ltd. The reason for review of fixed resources and capital ventures is the target assembling and assessing proof about financial activities and occasions with non-current resources and capital speculations with the point of setting up the level of consistence with these announcements the acknowledged standards of tax collection and bookkeeping and giving test results to intrigued clients. [13], [15] ,[ 17]

\section{Secondary Objectives}

- To study on the fixed assets management

- To study on the inventory and cost control measures

- To understand about financial auditing and its importance

\section{A. RESEARCH DESIGN:}

The examination configuration alludes to the general methodology that you coordinate the various parts of the investigation in a reasonable and legitimate way, in this manner, guaranteeing you will adequately address the exploration issue; it establishes the diagram for the gathering, estimation, and examination of information. Note that your examination issue decides the kind of plan you 
should utilize, not the a different way[19],[21],[23]

\section{B. STATISTICAL TOOLS USED:}

\section{RATIO ANALYSIS}

Proportion Analysis is a type of Financial Statement Analysis that is utilized to acquire a brisk sign of a company's budgetary exhibition in a few key zones. The proportions are classified as Short-term Solvency Ratios, Debt Management Ratios, Asset Management Ratios, Profitability Ratios, and Market Value Ratios. [20],[ 22], [24]

Table:1

\begin{tabular}{|l|l|}
\hline YEAR & AMOUNT OF RAW MATERIAL \\
\hline 2013 & 3613 \\
\hline 2014 & 3822 \\
\hline 2015 & 4005 \\
\hline 2016 & 3843 \\
\hline 2017 & 4397 \\
\hline
\end{tabular}

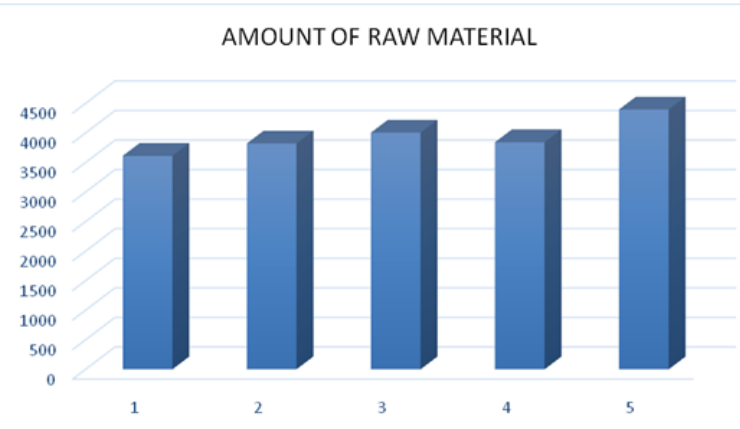

Fig:1

INTERPRETATION:

As shown in the table above the raw materials, work-in-process, and supplies declined from 2015 to 2016 but then increased from 2016 to 2017 exceeding 2015 level. Finished Goods:

These are the carrying amount as of the balance sheet date of merchandise or goods held by the company that are readily available for sale. [31],[33],[32]

Table:2

\begin{tabular}{|l|l|}
\hline YEAR & AMOUNT OF FINISHED GOODS \\
\hline 2013 & 5058 \\
\hline 2014 & 5022 \\
\hline 2015 & 5254 \\
\hline 2016 & 5943 \\
\hline 2017 & 6779 \\
\hline
\end{tabular}

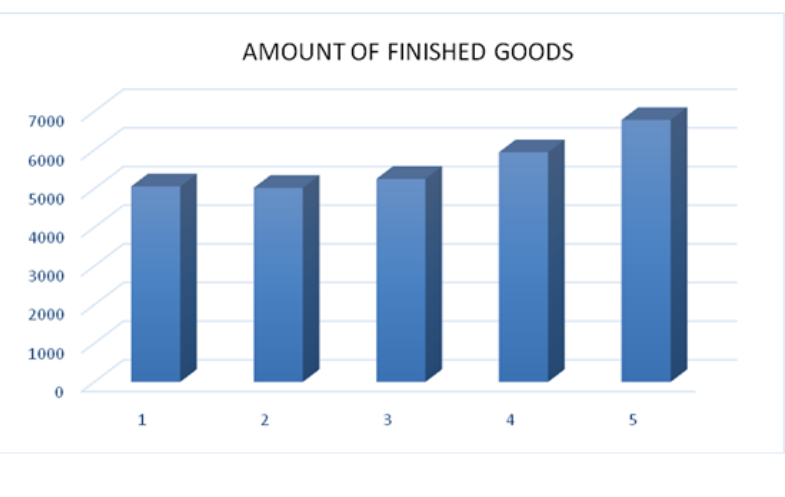

Fig:2

INTERPRETATION:

The above table shows that the finished products increased from 2015 to 2016 and from 2016 to 2017 . It shows a gradual increase in the amount of finished goods. [25],[27],[29]

\section{ECONOMIC ORDERING QUANTITY:}

Per year Ford India Pvt Ltd spends around 295,000,000 for aluminium coils, which is a major raw material for automobiles.

FORMULA:

$\mathrm{EOQ}=\sqrt{ } 2 \mathrm{AB} / \mathrm{C}$. Where,

A - Total quantity required

B - Ordering Cost per order

C - Carrying cost per unit DECEMBER 2013 - 2014:

The company requires the below given amount of raw materials of aluminium coils for the production of around 12,000 cars per month[26],[28],[30]

Table:3

\begin{tabular}{|l|l|}
\hline PARTICULARS \\
\hline Quantity & $1,691,000 \mathrm{~kg}$ \\
\hline Ordering cost per order & $1,97,000$ \\
\hline Purchase price Per unit & 157 \\
\hline Carrying cost & $12 \%$ \\
\hline
\end{tabular}

Table:4

\begin{tabular}{|l|l|}
\hline PARTICULARS \\
\hline Quantity & $1,523,000 \mathrm{~kg}$ \\
\hline Ordering cost per order & $2,38,000$ \\
\hline Purchase price Per unit & 160 \\
\hline Carrying cost & $10 \%$ \\
\hline
\end{tabular}

Table:5

\begin{tabular}{|l|l|}
\hline PARTICULARS \\
\hline Quantity & $1,680,000 \mathrm{~kg}$ \\
\hline Ordering cost per order & $2,72,000$ \\
\hline Purchase price Per unit & 173 \\
\hline Carrying cost & $14 \%$ \\
\hline
\end{tabular}

Table:6

\begin{tabular}{|l|l|l|l|}
\hline YEAR & NET FIXED ASSET & NET WORTH & RATIO \% \\
\hline $2016-17$ & 228928 & 29283 & 7.81 \\
\hline $2015-16$ & 216932 & 28751 & 7.56 \\
\hline $2014-15$ & 210546 & 28590 & 7.36 \\
\hline $2013-14$ & 204075 & 27685 & 7.37 \\
\hline
\end{tabular}
and Engin

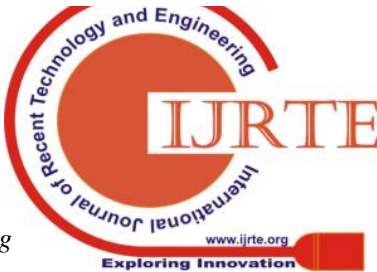




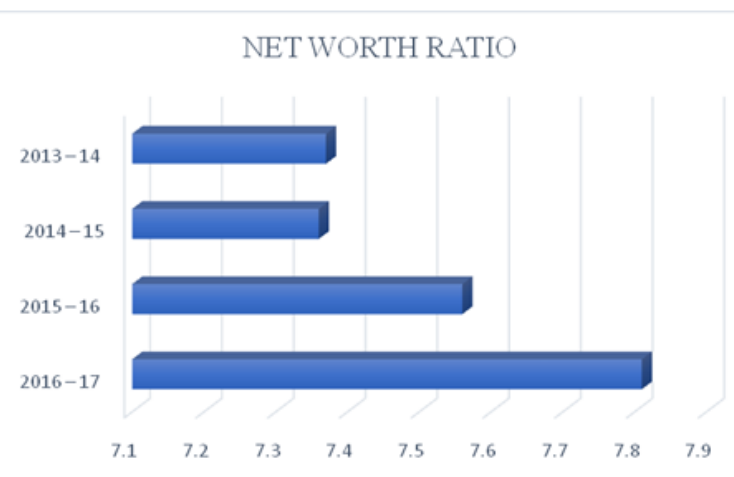

Fig:2

\section{INTERPRETATION}

The above table shows a continuous increase in Net worth and fixed assets. This shows the satisfactory position of the company.

\begin{tabular}{|l|l|l|l|}
\hline YEAR & NET FIXED ASSET & CAPITAL EMPLOYED & RATIO \% \\
\hline $2016-17$ & 228928 & 147670 & 1.55 \\
\hline $2015-16$ & 216932 & 142589 & 1.52 \\
\hline $2014-15$ & 210932 & 142510 & 1.48 \\
\hline $2013-14$ & 204075 & 142085 & 1.44 \\
\hline
\end{tabular}

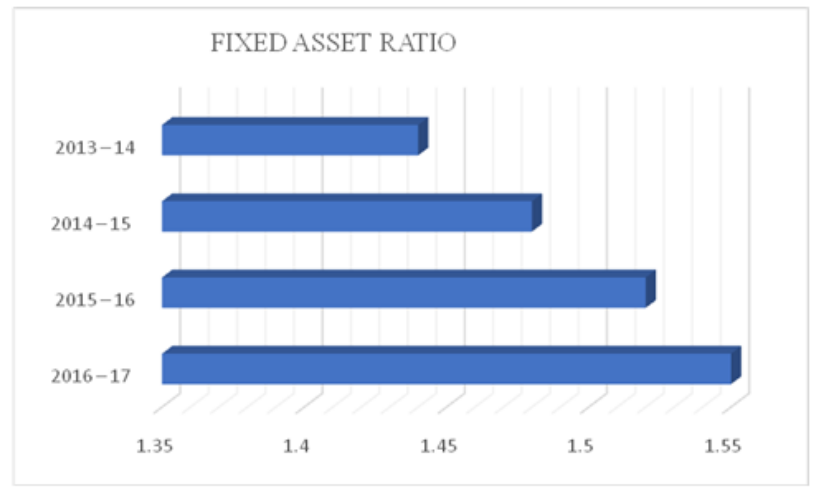

\section{INTERPRETATION:}

Fig:3

The above table shows growth in fixed assets satisfactory position of fixed assets in the total capital employed in the company. The highest percent 1.55 recorded in the year 2016 -17 . That shows the position of the company is satisfactory

Table:7

\begin{tabular}{|l|l|l|l|}
\hline YEAR & PROFIT AFTER TAX & TOTAL ASSETS & RATIO \% \\
\hline $2016-17$ & 4607 & 237951 & 0.019 \\
\hline $2015-16$ & 7371 & 224925 & 0.032 \\
\hline $2014-15$ & 1230 & 217931 & 5.6 \\
\hline $2013-14$ & 2451 & 211017 & 0.011 \\
\hline
\end{tabular}

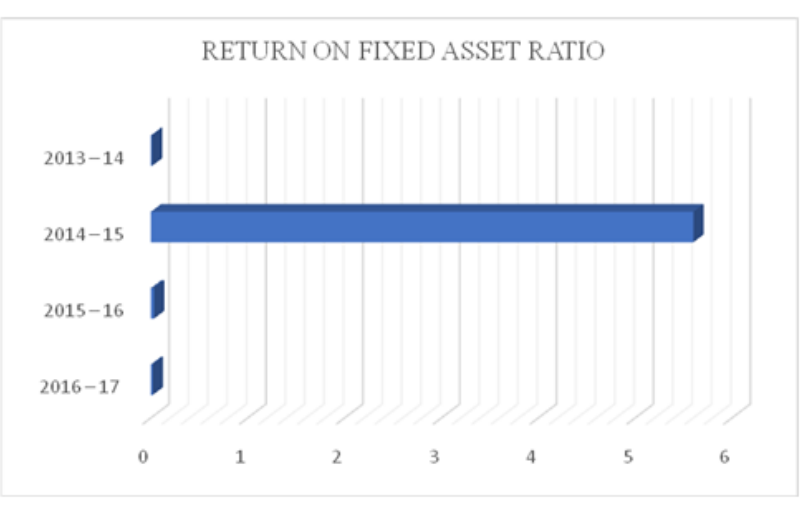

Fig:4

\section{INTERPRETATION}

The above table shows increase in profit during the year 2014 - 15 has gone up, this shows the favorable position of the company.

\begin{tabular}{|l|l|l|}
\hline YEAR & FIXED ASSETS & PERCENTAGE \\
\hline $2012-2013$ & 211,017 & 100 \\
\hline $2013-2014$ & 217,931 & 103.2765133 \\
\hline $2014-2015$ & 224,925 & 106.5909382 \\
\hline $2015-2016$ & 237,951 & 112.7639005 \\
\hline $2016-2017$ & 242,724 & 115.0258036 \\
\hline
\end{tabular}

Table:8

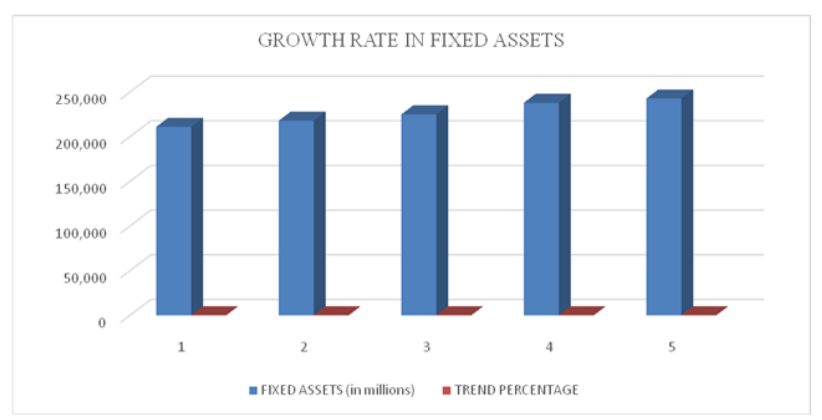

There is an expanding development in the benefits of the organization for as long as five years.

- Fixed assets the officials empowers the association to screen all points of interest. It can tell where the advantages are discovered, how they are used, and when changes were made to them. The data from the advantage the administrators game plan can ensure that preferred position recovery will provoke better returns.

- From the EOQ, the full scale yearly cost of the association during the years 2013 - 14 and 2015 - 16 where essentially same however, the year 2014 - 15 showed a trip.

- During the five years finished incredible is in extending point 
- Return on fixed asset is fluctuating during the past five years, in 2014-15 it was 5.6\%, anyway there was a massive ruin to $0.032 \%$ in the year $2015-16$ and again it has been reduces to $0.019 \%$ in $2016-17$.

- Net worth extent during the 5 years was in growing example anyway in 2014-15 it has to some degree lessens to $7.36 \%$.

- During the five years fixed asset extent is in the extending design, in $2016-17$ it was $1.55 \%$.

- The stock audits and affirmations are done physically at the respected stages.

- Scrap is being watched regularly and the system is done in each 31 days.

\section{DISCUSSION}

Keeping up ground breaking asset information by observing their region use overseer, backing and insurance could manufacture their gainfulness even more viably.

- Group fixed asset must be under $\$ 100000$, of which life should be more noticeable than 1 year.

- Low cost fixes asset may be obtained mass.

- Special instruments for venders are truly guaranteed by Ford that are at shipper's region are not checked in this way periodical affirmation should be conceivable that will benefit in holding assets.

- Retention of advantage affirmation are held under records at any rate for quite a while. Consistently the records are invigorated by the particular record's time range of convenience.

- The EOQ decided is suggesting that the association should get its stock requirements by putting orders a significant part of the opportunity to its suppliers.

- The return on fixed asset of the association is underneath the standard extent in all the five years, subsequently it should be improved at any rate to the standard.

\section{V.CONCLUSION}

The store division plays out the going with abilities to keep repaired assets especially kept. At the point when a preferred position is acquired and recorded, it is pursued. All the fixed assets are forever marked with a fixed asset name that contains a successive number. The number should contrast with a log book or the fixed asset module (the assistant record) of the accounting system.

Each fixed asset's physical territory is accounted for and any moves inside or outside the workplace are recorded. Any arrangements, new acquisitions, or salvages are in like manner be recorded to ensure fixed asset stock is to date.

Stock organization must be practiced for keeping exact records of product that are set up for creation. The association assembles the cycle check information and system it proficiently to take care of records. To know the veritable inventories that are available for age. Stock organization is critical for holding cost down, while meeting rule. Free market action is a delicate equality and this stock organization might want to ensure that the leveling is undisturbed.

\section{REFERENCES}

1. G BharthVajan R., Ramachandran S.,Psychographic dimensions of training,2016,International Journal of Pharmacy and Technology,V-8,I-4,P-23727-23729

2. Balakrishnan P., Bharthvajan R.,A study on human resource planning in hospitals in Chennai City,2014,International Journal of Applied Engineering Research,V-9,I-22,P-7503-7507

3. Priyadarsini P., Bharthvajan R.,Role of emotional intelligence training programme in reducing the stress of the nurses, 2014,International Journal of Applied Engineering Research,V-9,I-22,P-7411-7421

4. Kerinab Beenu G., Bharthvajan R.,Empirical analysis on the cosmetic buying behavior of young women in South India,2014,International Journal of Applied Engineering Research,V-9,I-22,P-7361-7366

5. Balakrishnan P., Bharthvajan R.,Whistling in the wind,2014,International Journal of Applied Engineering Research,V-9,I-22,P-7586-7593

6. Krishnan B., Peter M.,Health hazards of Indian Bpo employee-an alarming issue, 2014,International Journal of Applied Engineering Research,V-9,I-22,P-7336-7341

7. Kerinab Beenu G.H., Peter M.,Role of insurance in economic development,2014,International Journal of Applied Engineering Research,V-9,I-22,P-7532-7539

8. Balakrishnan P., Peter M., Priyadarsini P.,Efficiency of safety measures for wellbeing of employees in manufacturing industry,2014,International Journal of Applied Engineering Research,V-9,I-22,P-7376-7382

9. Anbarasi M., Praveen Kumar S.,Online sales promotions of herbal products and its effectiveness towards tanisha.com,2019,Indian Journal of Public Health Research and Development,V-10,I-1,P-195-200

10. Anbarasi M., Praveen Kumar S.,Various online marketing and promotions strategies to improve the validation towards the organic products in the pharmaceutical sectors,2019, Indian Journal of Public Health Research and Development,V-10,I-1,P-263-269

11. Loganathan R., Praveen Kumar S.,Grievance handling a key factor for solving issues of employees in an organization, 2014,International Journal of Applied Engineering Research,V-9,I-22,P-7483-7491

12. Loganathan R., Praveen Kumar S.,Study on preference of private label brands in super and Hypermarkets,2014,International Journal of Applied Engineering Research,V-9,I-22,P-7327-7335

13. Smitha M., Praveen Kumar S.,Understanding stress and its managementamong the nurses in Chennai city,2014,International Journal of Applied Engineering Research,V-9,I-22,P-7560-7565

14. Kerinab Beenu G.H., Praveen Kumar S.,A study on the investment behavior of Chennai investors in mutual fund schemes,2014,International Journal of Applied Engineering Research,V-9,I-22,P-7520-7525

15. Loganathan R., Praveen Kumar S.,Retention strategies key for organizational productivity,2014,International Journal of Applied Engineering Research,V-9,I-22,P-7443-7447

16. Pavithra J., Ganesan M., Brindha G.,State wise analysis of microfinance sector in India,2016,International Journal of Pharmacy and Technology,V-8,I-4,P-23417-23432

17. Pavithra J., Ganesan M.,A comparative study on microfinance in India and abroad,2016,International Journal of Applied Business and Economic Research,V-14,I-8,P-5471-5476

18. Pavithra J., Ganesan M.,A study on awareness and impact of micro-financial schemes,2016,International Journal of Applied Business and Economic Research,V-14,I-8,P-5449-5460

19. Senthilmurugan P., Pavithra J.,Consumer preference towards organised retailing with reference to Big Bazaar,2014,International Journal of Applied Engineering Research,V-9,I-22,P-7469-7475

20. Senthilmurugan P., Pavithra J.,Implication of social media marketing in growing healthcare industry,2014,International Journal of Applied Engineering Research,V-9,I-22,P-7448-7456 
21. Loganathan R., Pavithra J.,Consumer perception towards private label brand over other brands in super markets and hypermarkets,2014,International Journal of Applied Engineering Research,V-9,I-22,P-7355-7360

22. Kerinab Beenu G., Pavithra J.,Tradeâ€"off between liquidity and profitability in logistics industry,2014,International Journal of Applied Engineering Research,V-9,I-22,P-7398-7401

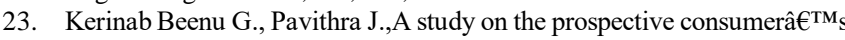
perception towards utility cars in Chennai city,2014,International Journal of Applied Engineering Research,V-9,I-22,P-7526-7531

24. Pavithra J., Dilli Babu P., Ambuli T.V.,A study on budgetary control at Maruti Service Masters, Chennai,2014,International Journal of Applied Business and Economic Research,V-12,I-2,P-151-161

25. Pavithra J., Dilli Babu P., Ambuli T.V.,A study on customer satisfaction of retro Garments Pvt Ltd, Chennai,2014,International Journal of Applied Business and Economic Research,V-12,I-2,P-381-391

26. Kerinab Beenu G.H., Pavithra J., Senthilmurugan P.,A study on the influence of promotional activities for TATA ARIA among consumers in Chennai,2014,International Journal of Applied Engineering Research,V-9,I-22,P-7572-7578

27. Vijayaragavan S.P.,An investigative expert that's general FBG sensors,International Journal of Mechanical Engineering and Technology,V-8,I-8,PP-1500-1505,Y-2017

28. Vijayaragavan S.P.,Equalization routing protocol for Wi-Fi sensor strategy,International Journal of Mechanical Engineering and Technology,V-8,I-8,PP-1662-1666,Y-2017

29. Karthik B., Kiran Kumar T.V.U., Vijayaragavan P., Bharath Kumaran E.,Design of a digital PLL using 0.35 $\hat{\mathrm{I}}^{1 / 4 \mathrm{~m}}$ CMOS technology,Middle East Journal of Scientific Research,V-18,I-12,PP-1803-1806,Y-2013

30. Kanniga E., Selvaramarathnam K., Sundararajan M.,Kandigital bike operating system,Middle - East Journal of Scientific Research, V

31. Jasmin M., Vigneshwaran T., Beulah Hemalatha S.,Design of power aware on chip embedded memory based FSM encoding in FPGA,International Journal of Applied Engineering Research,V-10,I-2,PP-4487-4496,Y-2015

32. Jasmin M.,Optimization techniques for low power VLSI circuits,Middle East Journal of Scientific Research,V-20,I-9,PP-1082-1087,Y-2014

33. Jasmin M., Vigneswaran T.,Fuzzy controller for error control of on - Chip communication,2017 International Conference on Algorithms, Methodology, Models and Applications in Emerging Technologies, ICAMMAET 2017,V-2017-January,I-,PP-1-5,Y-2017

\section{AUTHORS PROFILE}

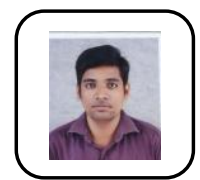

CS.Gowtham Assistant Professor ,Department of MBA Bharath Institute of Higher Education and Research, Tamilnadu, India

Dr.S.Praveen Kumar ,Professor ,Department of MBA Bharath Institute of Higher Education and Research, Tamilnadu, India

Dr.J.Hameed Hussain ,Professor ,Department of Mechanical Engineering, Bharath Institute of Higher Education and Research, Tamilnadu, India 